\title{
アルメニア正教教会堂建築における外壁面ニッチ構成の特質 DEVELOPMENT OF CATEGORY OF THE EXTERNAL NICHES ON ARMENIAN CHURCHES
}

\author{
藤田康仁 ${ }^{*}$ \\ Yasuhito FUJITA
}

\begin{abstract}
The present paper aims to clarify the morphological characteristics of the external niches on medieval Armenian churches, through comparative analyses on the position in the monument, the form, the stone composition and decorative elements with them. As a result, the function of the external niches as a simplified method for avoiding complicated external roofs and wall construction is newly discovered. Additionally, the chronological changes on the above-mentioned four dimensions are totally interpreted that the several initial functions played by the external niches in the seventh century gradually receded and their function converged with decorative composition on external wall.
\end{abstract}

Keywords : Christian Architecture, Armenia, External Niches, Construction Techniques キリスト教建築, アルメニア, 外壁面ニッチ, 構築方法

\section{1. はじめに}

東アナトリアからコーカサス一帯に亘る歴史的アルメニア地域に は、キリスト教の伝来以来、アルメニア正教教会堂建築（以下、ア ルメニア建築と呼称する）が数多く建設されてきた。この建築群に ついては、ビザンツ建築やイスラーム建築を含む東アナトリア一帯 の建築文化の展開を考える上でも重要な建築群と捉えられ、20世 紀初頭よりその研究が進められてきたが、特に近年では、東京工業 大学を中心とした研究組織による一連の調査研究によって、その特 質の一端が明らかにされてきた。具体的には、ドーム架構を中心と

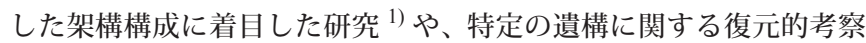

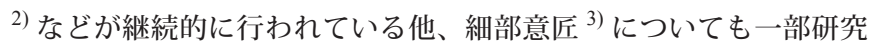
が進められてきた。細部意匠に関する研究に関しては、これまでも 試論としてその特質が明らかにされてきたが、調査研究及び遺構デー タの蓄積から、網羅的な分析が昨今可能になってきたといえる。

ここで、アルメニア建築にみられる細部意匠を通観すると、外壁 面にしばしば設けられるニッチ状の構成（図 1。以下、外壁面ニッ チと呼称する）が注目される。グルジア正教の教会堂にも認められ ることから、コーカサス地域の教会堂建築に特有の形式とも指摘さ れるこの部位は、時代を通じて、比較的多くの遺構において使用が 認められ ${ }^{4)}$ 、外壁面を構成する部位としては比較的大きいことから、 今日までに多少の修復がなされたにせよ、創建当初の姿を保持して
いる可能性が高い部位といえる ${ }^{5)}$ 。すなわち、アルメニア建築の特 質について、その年代的な検討を行う上で、有効な建築部位のひと つと捉えられる。しかし、この外壁面ニッチに関しては、既往研究 として、Khatchatrianや Eremian による論稿が認められるものの、平 面形状にのみ着眼している点や、特定の遺構のみを取り上げて検討 している点にみられるように、いずれも限定的な検討に留まってお り、詳細かつ悉皆的な分析に基づいた研究はなされていない6)。

そこで本研究では、この外壁面ニッチに着目し、その形態的な特 徵の分析を通じて、アルメニア建築における外壁面ニッチの年代的 な変化を把握するとともに、この部位にみられる傾向から、外壁面 ニッチの特質を明らかにすることを目的とする。研究対象範囲とし ては、外壁面ニッチの使用が認められるようになる最初である7世 紀から、一般にアルメニア建築の建築形式が概ね完成したものと捉 えられる14世紀までを研究対象年代とし、具体的には、アルメニア 共和国及びナゴルノ・カラバフ自治州、トルコ共和国東部地域に分 布するアルメニア建築45棟（表1）を対象とする7)。主な平面形式 を図2に示した。また、分析に当たっては、これまでに行われたア ルメニア共和国、グルジア共和国、トルコ共和国の各地における現 地調査 ${ }^{8)}$ より作成された、写真撮影資料や実測データに基づいて行 うものとし ${ }^{9)}$ 、平面実測など充分なデータを得られていない遺構に ついては、Cuneoの著作を中心にデータを補完している ${ }^{10)}$ 。
* 東京工業大学大学院総合理工学研究科人間環境システム専攻 助教 $\cdot$ 博士 (工学)
Assistant Prof., Department of Built Environment, Interdisciplinary Graduate School of Science and Engineering, Tokyo Institute of Technology, Dr. Eng. 


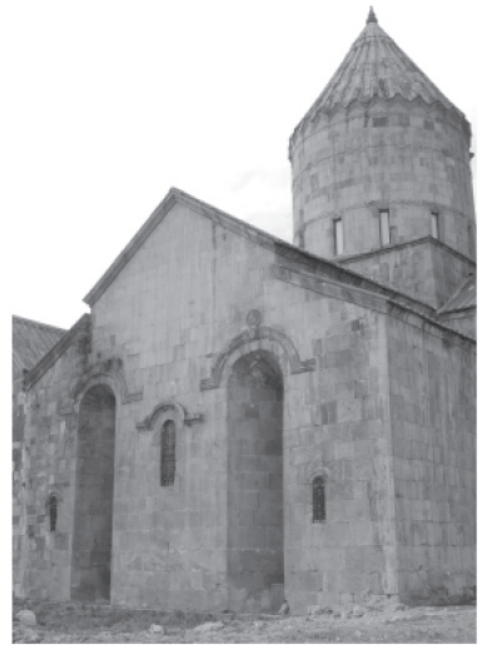

図 1 外壁面ニッチの例

(Tatev, SS. Poghos Petros)

表 1 分析対象遺構一覧

\begin{tabular}{|c|c|c|c|c|c|}
\hline 遺構名称 & 平面類型 & 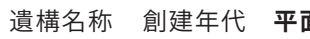 & 面類型 & 遺構名称 & F面類型 \\
\hline Vagharshapat/S. Hripsime & 7 hp & Kecharis/S. Grigor & $11 \mathrm{dh}$ & Akhtala/S. Astvatsatsin & $13 \mathrm{db}$ \\
\hline Garnahovit/S. Gevorg & 7 hp & Bjni/S. Astvatsatsin & $11 \mathrm{dh}$ & Makaravank/Main church & $13 \mathrm{mo}$ \\
\hline Sisavan/S. Hovhannes & 7 hp & Amberd & $11 \mathrm{mo}$ & Haghartsin/S. Stepanos & $13 \mathrm{dh}$ \\
\hline Yeghvard/Zoravar S. Teodoros & $7 \mathrm{f} 8$ & Sanahin/S. Grigor chapel & $11 \mathrm{f} 4$ & Haghartsin/S. Astvatsatsin & $13 \mathrm{dh}$ \\
\hline Arutsh/S. Grigor & $7 \mathrm{dh}$ & Tsaghatskar East/S. Karapet & t $11 \mathrm{mo}$ & Goshavank/Mkhtar Gosh's chap. & $131 \mathrm{n}$ \\
\hline Oğuzlu & 9 f3 & Bgheno Noravank & 11 1n & Goshavank/S. Grigor & $13 \mathrm{mo}$ \\
\hline Shoghaghavank & 9 f3 & Makaravank/S. Astvatsatsin & $12 \mathrm{dh}$ & Aghjotsvank/S. Stepanos & $13 \mathrm{mo}$ \\
\hline Makenotsatsvank/S. Astvatsa & atsin $9 \mathbf{f 3}$ & Goshavank/S. Astvatsatsin & $12 \mathrm{dh}$ & Noravank Amaghu/S. Karapet & $13 \mathrm{mo}$ \\
\hline Haykadzor & $10 \mathrm{dh}$ & Kecharis/Katoghike & $13 \mathrm{mo}$ & Gtits/Main church & $13 \mathrm{dh}$ \\
\hline Haghbat/S. Nshan & $10 \mathrm{dh}$ & Teghervank/Main Church & 13 mo & Ganjasar & $13 \mathrm{mo}$ \\
\hline Ani/S. Grigor Abughamrents & $10 \mathrm{f6}$ & Saghmosavank/S.Sion & $13 \mathrm{mo}$ & Dadivank/Katoghike & $13 \mathrm{mo}$ \\
\hline Orotnavank & $10 \mathbf{f 3}$ & Hovhannavank/Main Church & $13 \mathrm{mo}$ & Ani/S. Grigor of Tigran Honents & $13 \mathrm{mo}$ \\
\hline Tatev/SS. Poghos Petros & $10 \mathrm{mo}$ & Astvatsenkal/S. Nshan & $13 \mathrm{mo}$ & Kızıl Kilisesi & $13 \mathrm{mo}$ \\
\hline Marmashen/Katoghike & $10-11 \mathrm{dh}$ & Hogevank/S. Karapet & $13 \mathbf{d h}$ & Hovhannes Karapet & $14 \mathrm{dh}$ \\
\hline Ani/Katoghike & $11 \mathbf{d b}$ & Harichavank/S. Astvatsatsin & $13 \mathrm{mo}$ & Areni/S. Astvatsatsin & $14 \mathrm{dh}$ \\
\hline
\end{tabular}

表 1 注 : 特に遺構の名称が明らかでない場合は地名に代えて遺構名称として いる。また、略号が示す平面形式は以下の通り。

f3: 三葉形、f4: 四葉形、f6: 六葉形、f8: 八葉形、hp: リプシメ型、dh: ドーム・ ホール型、 $\mathrm{db}$ : ドーム・バシリカ型、mo: 修道院型、1 $1 \mathrm{n}$ : 単廊型

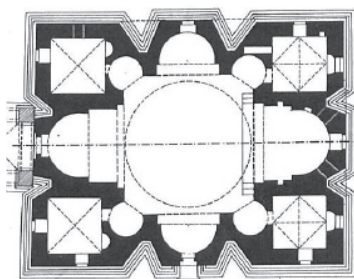

リプシメ型

(Vagharshapat, S. Hripsime, 7th cen.)

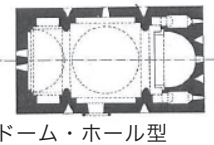

(Haykadzor, 10th cen.)

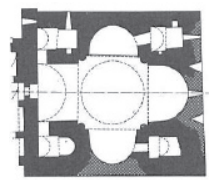

三葉形 (Orotnavank, 10th cen.)
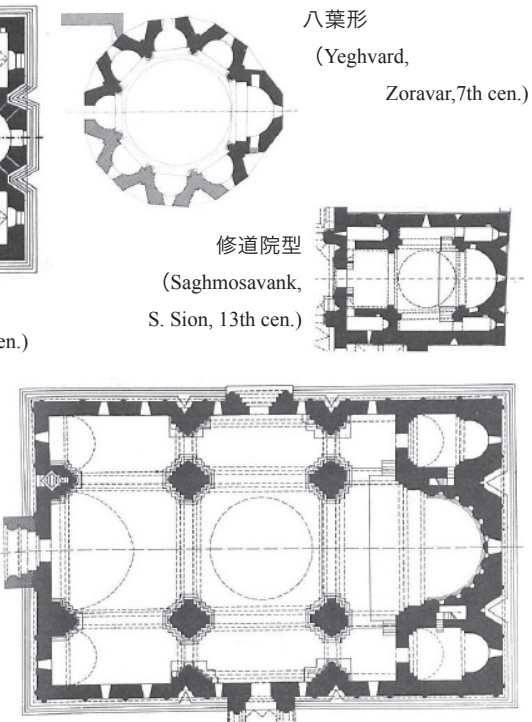

ドーム・バシリカ型 (Ani, Kathoghike, 11th cen.)

図 2 検討対象のアルメニア建築における主な平面形式

※これらの図面は、Cuneo, P., Architettura Armena, Roma, 1988より引用している。

\section{2. 外壁面ニッチの分類項目}

本稿では、外壁面ニッチの形態的な特質を数量的に把握するた め、外壁面ニッチが設けられる「位置」、外壁面ニッチの全体的な 形や大きさである「形状」、外壁面ニッチを構成する石材の組み方 である「構法」、外壁面ニッチ及びその周辺に施される「装飾」の、 大きく 4 つの観点から分類項目を設定した。各分類項目の具体的な 内容について、以下に記述する。なお、外壁面ニッチを記述する際、 外壁面ニッチを構成する部位について、表層石材の取り合いを区分 の指標として、すなわち、その部分の石材が外壁面ニッチの壁壠部 分を構成するか否かを基準として、図 3 のように定めることとした。 a. 位置 : 教会堂の建築平面上のどの位置に設けられるのか、外壁面 ニッチの設置された外壁面の向く方位をみた他、これまで対応関係 が指摘されている、建築内部におけるアプス状平面との関係につい て、その是非を抽出した ${ }^{11)}$ 。方位については、東西南北の各方位 を基本に分類している。また、外壁面ニッチの用法上、基本的に対 として設けられることから ${ }^{12)}$ 、方位の分析では、遺構数を計上し

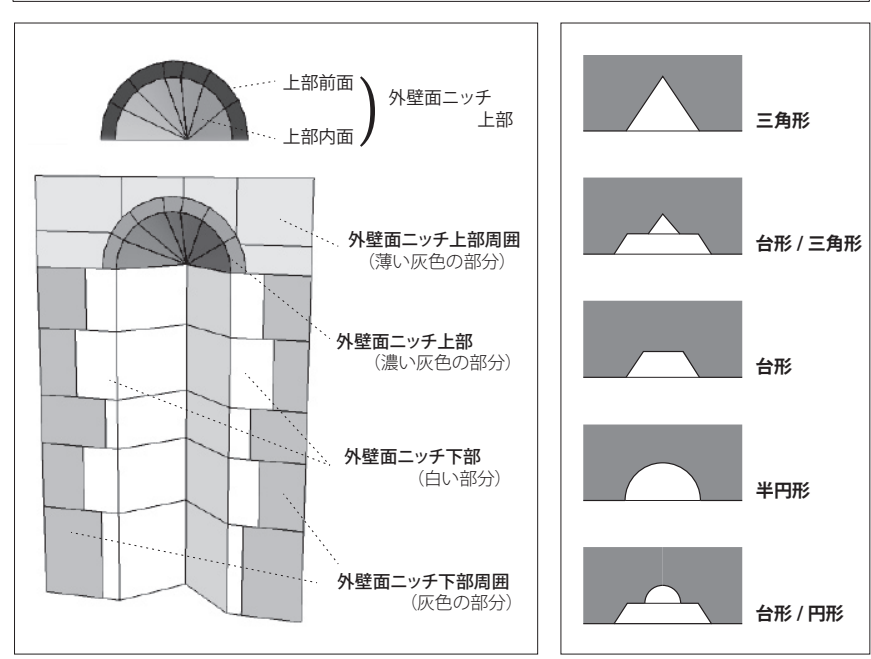

図 3 外壁面ニッチの部位区分

図 4 外壁面ニッチの水平断面形状

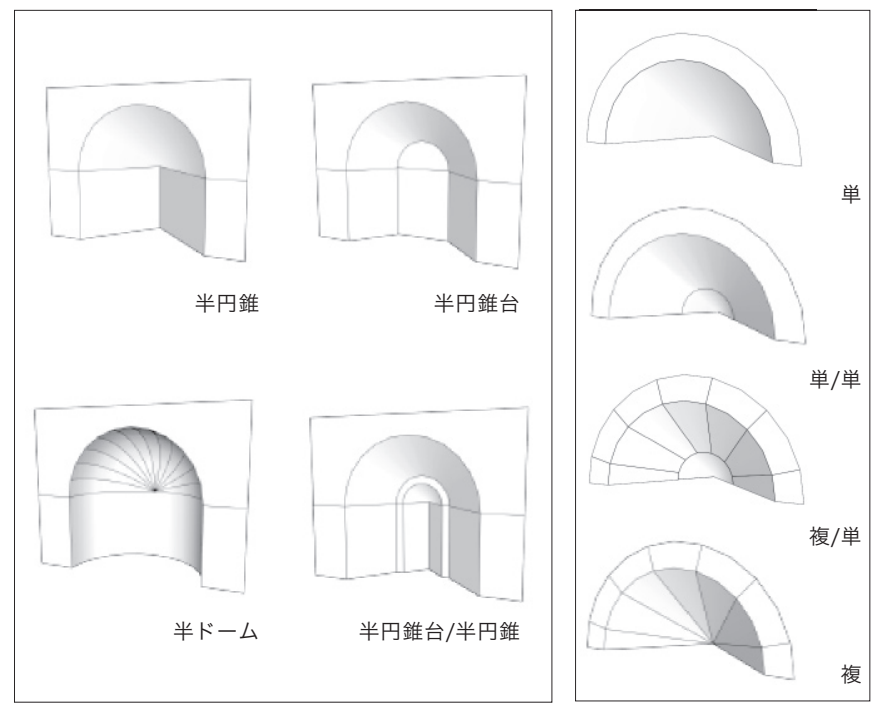

図 5 外壁面ニッチの上部形状

図 6 外壁面ニッチ上部の構法

て検討するものとした。

b. 形状：外壁面ニッチの凡その形状を把握する指標として、外壁 


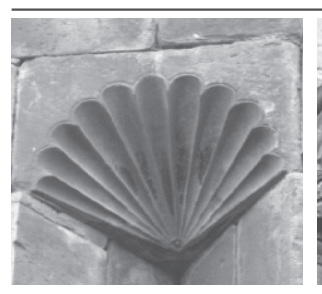

a. 放射状彫刻

扇状に配される楔形浮彫

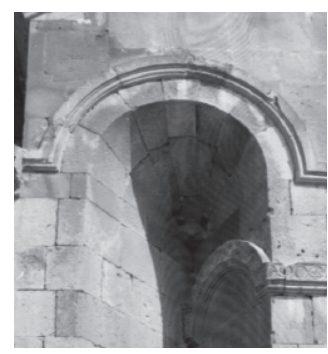

g. フード

$\Omega$ 形の装飾帯

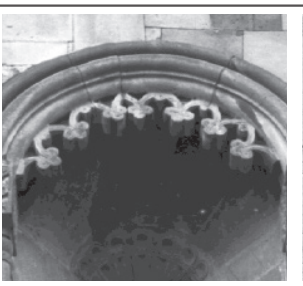

b. 垂れ飾り

上部前面に垂れる装飾

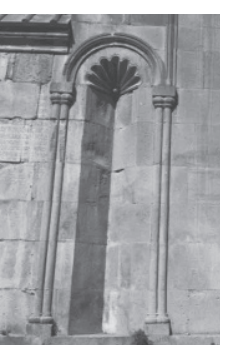

h. アーケード

ブラインド・アーケード状の装飾 内部に設けられる空構成

c. 彩色

顔料等による彩色

i. 空
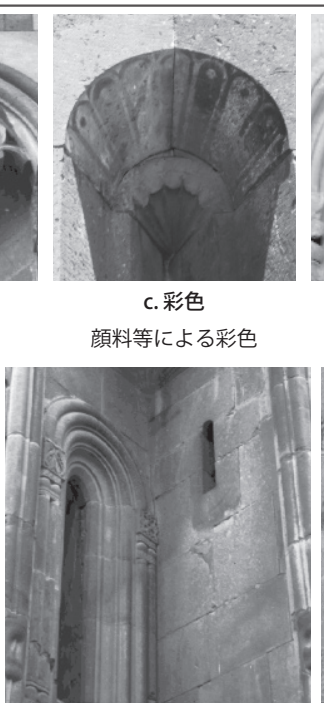

図 7 外壁面ニッチにおける主な装飾要素

面ニッチ中段における水平方向の断面形状、外壁面ニッチ上部を覆 う架構部分の形状をみるとともに、外壁面ニッチの大きさとして、 その開口幅と奥行を実測平面図より算出した ${ }^{13)}$ 。また、奥行につい ては建築壁面の厚さとの関係も想定されることから、壁厚に対する比 （以下、 $\alpha$ とする）も併せて計算している ${ }^{14)}$ 。この值 $\alpha$ は、壁厚に対 してどれだけの深さをもって外壁面ニッチが設けられているのかを示 すものであり、時代を通じて極端に壁厚は変わらないことから、建物 に対する外壁面ニッチの大きさを示す指標として捉えられる。水平方 向断面及び上部形状に関する分類については、図 4 及び図 5 に示した。 c. 構法 : 本稿では、外壁面ニッチ上部における構法について検討す る ${ }^{15)}$ 。同箇所を概観すると、図 6 に示すように、上部を単一の石 材から構成する「単」、上部の外周部と内奥部とをそれぞれひとつ の石材で構成する「単/単」、上部外周部を複数の石材から構成し、 内奥部に単一の石材を用いた「複/単」、上部全体を複数の石材に よって構成する「複」の 4 つに分類できた。

d. 装飾 ${ }^{16)}$ : 装飾的要素の取扱いについては、外壁面ニッチ全体に対す る装飾の有無についてみた上で、上述の 4 区分（図 2 参照）に分けて 検討した。ここでは、具体的な彫刻装飾のモチーフなど、細部に亘る 意匠までは検討の対象とせず、フードやアーケードといった、外壁面 ニッチ構成にまつわる、比較的大きなまとまりをもつ装飾要素に基づ いて分類を行っている。使用が認められる装飾要素を図 7 に示す。

\section{3. 各項目における外壁面ニッチの傾向（表 $2^{17)}$ )}

a. 位置：方位（表 2A）については、東面に外壁面ニッチを設ける 遺構は 42 棟と、外壁面ニッチを用いた遺構全体の $93 \%$ 占めてい る。各創建年代の総棟数に対する該当遺構の割合をみても、時代を 通じて、東面への使用が多く認められる。南面については、11 世 紀を除く各年代において、半数以上の遺構で外壁面ニッチの設置が みられる。北面についても $11 、 12$ 世紀以外の各年代において、半 数以上の遺構で設けられている。一方、西面については、7 世紀を 除くと、殆ど設けられていない。

また、外壁面ニッチと内部平面の対応関係（表 2B）をみると、

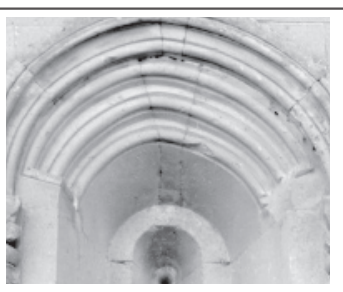

d. アーチ

丸形断面の縁によるアーチ

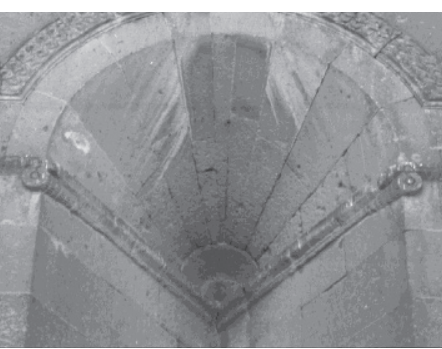

j. 見切縁

内部に回り込む水平の装飾帯

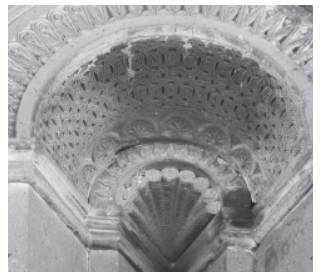

e. 浮彫

内面に面的に施された浮彫

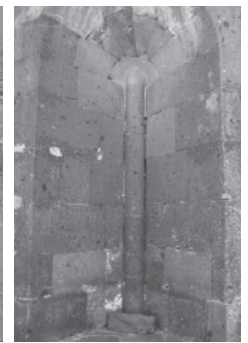

k. 付柱

最奥に設けられる付柱

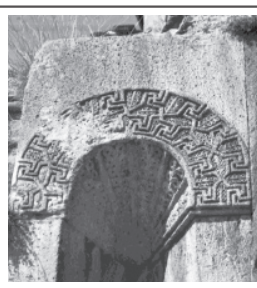

f. 帯状彫刻

前面につく帯状の浮彫

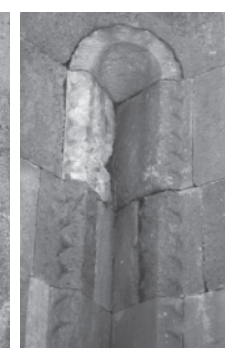

I. 連続半円紋

半円形浮彫の連続
13 世紀を除けば、時代を通じて、外壁面ニッチが内部アプス状平 面の背後に位置するものの方が、より多くみられる。詳しくみる と、9 世紀までは、アプス状平面の背後に位置する割合が極めて高 い一方、10 世紀以降では、内部にアプス状平面のない外壁面に設 けられる割合が比較的高くなり、13 世紀に至っては、半数以上の 外壁面ニッチが内部にアプスをもたない壁面に設けられている。つ まり、アプス状平面の背後に多く設けられていた外壁面ニッチは年 代が下るにつれ、アプスのない外壁面にもニッチが設けられるよう になる傾向にあるといえる。

b. 形状 ${ }^{18)}$ : 断面形状（表 2C）については、「三角形」断面が 168 例で確認され、全体の 77\%を占めている。各創建年代のニッチ総 数に対する、断面形状の使用割合をみると、年代によって多少の多 寡はあるものの、いずれの創建年代においても、「三角形」が多く を占めている。この他の断面形状については、7 世紀や 13 世紀に おいて、「台形」や「台形 / 三角形」など幾つかの断面形状の種類 が認められるものの、全体としては少ない。

上部形状（表 2D）については、全体的には「半円錐」形が最も 多く、107例（全体の 57\%）でみられる。次に多い「半円錐台/半 円錐」形状は 7 世紀にはみられないが、9 世紀以降に認められ、特 に 11 世紀では「半円錐」と同程度の割合で用いられている。「半円 錐台」は 7 世紀にのみ、「半ドーム」は 7、9 世紀にのみ認められ、 その後の時代では全くみられない。「半円錐台/半円錐」の形状が、 円錐形の内部に形状的な分節をもつのみで、全体としては円錐形状 であることを考えると、外壁面ニッチ上部の形状は、基本的には半 円錐形状であったといえる。

大きさについて、外壁面ニッチの開口幅（表 2E）をみると、全 体的な傾向として、9 世紀までは 1,000mm 未満の外壁面ニッチが ない一方、10 世紀以降に $1,000 \mathrm{~mm}$ 未満のものが多く認められる。 創建年代ごとにみると、 7 世紀では $1,000 \mathrm{~mm}$ 以上 $1,500 \mathrm{~mm}$ 未満と $2,000 \mathrm{~mm}$ 以上 $2,500 \mathrm{~mm}$ 未満、9 世紀では $1,000 \mathrm{~mm}$ 以上 $1,500 \mathrm{~mm}$ 未 満と $1,500 \mathrm{~mm}$ 以上 $2,000 \mathrm{~mm}$ 未満、10 世紀では $500 \mathrm{~mm}$ 以上 $1,000 \mathrm{~mm}$ 未満、11 世紀では $500 \mathrm{~mm}$ 以上 $1,000 \mathrm{~mm}$ 未満のものと $1,000 \mathrm{~mm}$ 以 
表 2 アルメニア建築における外壁面ニッチの形態的特徴にみる年代的傾向

A : 方位

\begin{tabular}{|c|c|c|c|c|c|c|c|c|}
\hline 方位 & 7th & 9th & 10th & 11th & 12th & 13th & 14th & 計 \\
\hline 東 & $5(100)$ & $3(100)$ & $4(80)$ & $7(88)$ & $1(50)$ & $20(100)$ & $2(100)$ & $42(93)$ \\
\hline 西 & $4(80)$ & 0 & 0 & 0 & 0 & $4(21)$ & 0 & $8(18)$ \\
\hline 南 & $4(80)$ & $2(67)$ & $3(60)$ & $3(38)$ & $1(50)$ & $15(75)$ & $1(50)$ & $29(64)$ \\
\hline 北 & $4(80)$ & $2(67)$ & $3(60)$ & $2(25)$ & 0 & $13(68)$ & $1(50)$ & $25(56)$ \\
\hline 南東 & 0 & 0 & $1(20)$ & $1(13)$ & $1(50)$ & 0 & 0 & $3(7)$ \\
\hline 南西 & 0 & 0 & $1(20)$ & $1(13)$ & $1(50)$ & 0 & 0 & $3(7)$ \\
\hline 北東 & 0 & 0 & $1(20)$ & $1(13)$ & $1(50)$ & 0 & 0 & $3(7)$ \\
\hline 北西 & 0 & 0 & $1(20)$ & 0 & $1(50)$ & 0 & 0 & $2(4)$ \\
\hline 該当遺構数 & 5 & 3 & 5 & 8 & 2 & 20 & 2 & 45 \\
\hline
\end{tabular}

B : 内部アプス平面との対応

\begin{tabular}{|c|c|c|c|c|c|c|c|c|}
\hline 内部アプス対応 & 7 th & 9th & 10th & 11th & 12th & 13th & 14th & 計 \\
\hline 無 & $4(11)$ & 0 & $8(36)$ & $10(37)$ & $2(25)$ & $62(61)$ & $4(50)$ & $90(41)$ \\
\hline 有 & $34(89)$ & $14(100)$ & $14(64)$ & $17(63)$ & $6(75)$ & $40(39)$ & $4(50)$ & $129(59)$ \\
\hline 該当ニッチ数 & 38 & 14 & 22 & 27 & 8 & 102 & 8 & 219 \\
\hline
\end{tabular}

\section{C : 水平断面形状}

\begin{tabular}{|c|c|c|c|c|c|c|c|c|}
\hline 断面形状 & 7th & 9th & 10th & 11th & 12th & 13th & 14th & 計 \\
\hline 三角形 & $17(45)$ & $8(57)$ & $22(100)$ & $15(56)$ & $8(100)$ & $92(90)$ & $6(75)$ & $168(77)$ \\
\hline 台形/三角形 & 0 & 0 & 0 & $12(44)$ & 0 & $8(8)$ & $2(25)$ & $22(10)$ \\
\hline 台形 & $15(39)$ & 0 & 0 & 0 & 0 & 0 & 0 & $15(7)$ \\
\hline 半円形 & $4(11)$ & $6(43)$ & 0 & 0 & 0 & 0 & 0 & $10(5)$ \\
\hline 台形/半円形 & $2(5)$ & 0 & 0 & 0 & 0 & $2(2)$ & 0 & $4(2)$ \\
\hline 該当ニッチ数 & 38 & 14 & 22 & 27 & 8 & 102 & 8 & 219 \\
\hline
\end{tabular}

\section{$D$ ：上部形状}

\begin{tabular}{|c|c|c|c|c|c|c|c|c|}
\hline 上部形状 & 7th & 9th & 10th & 11th & 12th & 13th & 14th & 計 \\
\hline 半円錐 & $14(40)$ & $2(22)$ & $6(43)$ & $8(32)$ & $8(100)$ & $63(71)$ & $6(75)$ & $107(57)$ \\
\hline 半円錐台/半円錐 & 0 & $5(56)$ & $8(57)$ & $17(68)$ & 0 & $23(26)$ & 0 & $53(28)$ \\
\hline 半円錐台 & $15(43)$ & 0 & 0 & 0 & 0 & 0 & 0 & $15(8)$ \\
\hline 半ドーム & $4(11)$ & $2(22)$ & 0 & 0 & 0 & 0 & 0 & $6(3)$ \\
\hline その他 & $2(6)$ & 0 & 0 & 0 & 0 & $3(3)$ & $2(25)$ & $7(4)$ \\
\hline 該当ニッチ数 & 35 & 9 & 14 & 25 & 8 & 89 & 8 & 188 \\
\hline
\end{tabular}

\section{E : 開口幅長さ}

\begin{tabular}{|c|c|c|c|c|c|c|c|c|}
\hline ニッチ開口幅W & 7th & 9th & 10th & 11th & 12th & 13th & 14th & 計 \\
\hline$w<500 \mathrm{~mm}$ & 0 & 0 & 1 (5) & $3(11)$ & 0 & $19(19)$ & 0 & $23(11)$ \\
\hline $500 \mathrm{~mm} \leqq \mathrm{w}<1,000 \mathrm{~mm}$ & 0 & 0 & $10(48)$ & $7(26)$ & $6(75)$ & $71(70)$ & $8(100)$ & $102(47)$ \\
\hline $1,000 \mathrm{~mm} \leqq \mathrm{w}<1,500 \mathrm{~mm}$ & $11(30)$ & $8(57)$ & $5(24)$ & $9(33)$ & $2(25)$ & 9(9) & 0 & $44(20)$ \\
\hline $1,500 \mathrm{~mm} \leqq w<2,000 \mathrm{~mm}$ & $8(22)$ & $6(43)$ & $5(24)$ & $6(22)$ & 0 & $1(1)$ & 0 & $26(12)$ \\
\hline $2,000 \mathrm{~mm} \leqq \mathrm{w}<2,500 \mathrm{~mm}$ & 12(32) & 0 & 0 & $2(7)$ & 0 & $1(1)$ & 0 & $15(7)$ \\
\hline $2,500 \mathrm{~mm} \leqq \mathrm{w}<3,000 \mathrm{~mm}$ & $4(11)$ & 0 & 0 & 0 & 0 & 0 & 0 & $4(2)$ \\
\hline $\mathrm{w} \leqq 3,000 \mathrm{~mm}$ & $2(5)$ & 0 & 0 & 0 & 0 & 0 & 0 & $2(1)$ \\
\hline 該当ニッチ数 & 37 & 14 & 21 & 27 & 8 & 101 & 8 & 216 \\
\hline
\end{tabular}

\section{$F:$ 奥行長さ}

\begin{tabular}{|c|c|c|c|c|c|c|c|c|}
\hline ニッチの奥行 $d$ & 7th & 9th & 10th & 11th & 12th & 13th & 14th & 計 \\
\hline$d<500 \mathrm{~mm}$ & 0 & 0 & $2(10)$ & $6(22)$ & $8(100)$ & $67(66)$ & $8(100)$ & $91(42)$ \\
\hline $500 \mathrm{~mm} \leqq \mathrm{~d}<1,000 \mathrm{~mm}$ & $7(18)$ & $8(57)$ & $14(67)$ & $10(37)$ & 0 & $32(32)$ & 0 & $71(33)$ \\
\hline $1,000 \mathrm{~mm} \leqq \mathrm{~d}<1,500 \mathrm{~mm}$ & $19(50)$ & $2(14)$ & $5(24)$ & $9(33)$ & 0 & $1(1)$ & 0 & $36(17)$ \\
\hline $1,500 \mathrm{~mm} \leqq \mathrm{~d}<2,000 \mathrm{~mm}$ & $8(21)$ & $4(29)$ & 0 & $2(7)$ & 0 & $1(1)$ & 0 & $15(7)$ \\
\hline $\mathrm{d} \leqq 2,000 \mathrm{~mm}$ & $4(11)$ & 0 & 0 & 0 & 0 & 0 & 0 & $4(2)$ \\
\hline 該当ニッチ数 & 38 & 14 & 21 & 27 & 8 & 101 & 8 & 217 \\
\hline
\end{tabular}

\section{G：壁厚に対する奥行の割合}

\begin{tabular}{|c|c|c|c|c|c|c|c|c|}
\hline$\alpha=$ 奥行/壁厚 & 7th & 9th & 10th & 11th & 12th & 13th & 14th & 計 \\
\hline$\alpha \geqq 1$ & $28(82)$ & $10(71)$ & $10(48)$ & $16(59)$ & 0 & $2(2)$ & 0 & $66(31)$ \\
\hline $0.5 \leqq \alpha<1$ & $6(18)$ & $4(29)$ & $9(43)$ & $8(30)$ & $7(88)$ & $46(46)$ & $2(25)$ & $82(39)$ \\
\hline$\alpha<0.5$ & 0 & 0 & $2(10)$ & $3(11)$ & $1(13)$ & $53(53)$ & $6(75)$ & $65(31)$ \\
\hline 該当ニッチ数 & 34 & 14 & 21 & 27 & 8 & 101 & 8 & 213 \\
\hline
\end{tabular}

\section{表 2 及び表 3 注}

・外壁面ニッチによっては崩壊等により上部が失われるなどして全ての形態 的な特質を知り得ない場合があるため、表によって外壁面ニッチの総数は 異なっている。

・括弧内の数字は、各年代の該当ニッチ数に対する百分率を、横軸には創建 年代を示している。

• 割合の高い度数より順に色付けしており、最も濃い（黒い）100\%より順に、 $75 \%$ までを濃い灰色、50\%までを中間の灰色、25\%までを薄い灰色となっ ている。

・装飾に関する表における装飾要素の百分率は、「装飾あり」に該当する外 壁面ニッチの総数を分母としている。

H : 上部における構法
\begin{tabular}{|c|c|c|c|c|c|c|c|c|}
\hline 上部構法 & 7 7th & 9th & 10 th & 11 th & 12th & 13th & 14 th & 計 \\
\hline 単 & 0 & 0 & $1(7)$ & $7(28)$ & $8(100)$ & $65(74)$ & $6(75)$ & $87(47)$ \\
\hline 単/単 & 0 & 0 & 0 & $1(4)$ & 0 & $3(3)$ & 0 & $4(2)$ \\
\hline 複/単 & $10(29)$ & $7(78)$ & $11(79)$ & $15(60)$ & 0 & $18(21)$ & $2(25)$ & $63(34)$ \\
\hline 複 & $25(71)$ & $2(22)$ & $2(14)$ & $2(8)$ & 0 & $2(2)$ & 0 & $33(18)$ \\
\hline 該当ニッチ数 & 35 & 9 & 14 & 25 & 8 & 88 & 8 & 187 \\
\hline
\end{tabular}

\section{I：外壁面ニッチに用いられる装飾要素}

\begin{tabular}{|c|c|c|c|c|c|c|c|c|}
\hline 装飾要素の有無 & 7th & 9th & 10th & 11th & 12th & 13th & 14th & 計 \\
\hline 装飾なし & $14(37)$ & $4(44)$ & 0 & $4(14)$ & 0 & $6(7)$ & 0 & $28(14)$ \\
\hline 装飾あり & $24(63)$ & $5(56)$ & $15(100)$ & $22(86)$ & $8(100)$ & $84(93)$ & $8(100)$ & $166(86)$ \\
\hline 該当ニッチ数 & 38 & 9 & 15 & 26 & 8 & 90 & 8 & 194 \\
\hline
\end{tabular}

\section{$\mathrm{J}:$ 上部に用いられる装飾要素}

\begin{tabular}{|c|c|c|c|c|c|c|c|c|c|}
\hline \multicolumn{2}{|c|}{ 上部装飾 } & 7th & 9th & 10th & 11 th & 12th & 13th & 14th & 計 \\
\hline \multicolumn{2}{|c|}{ 装飾なし } & $38(100)$ & $4(44)$ & $9(64)$ & $7(27)$ & 0 & $12(13)$ & 0 & $70(36)$ \\
\hline \multicolumn{2}{|c|}{ 装飾あり } & 0 & $5(56)$ & $5(36)$ & 19(73) & $8(100)$ & 79(87) & $8(100)$ & $124(64)$ \\
\hline \multirow{6}{*}{$\begin{array}{c}\text { 上部内面の } \\
\text { 装飾要素 }\end{array}$} & 放射状周刻 & 0 & $5(100)$ & $5(100)$ & $12(63)$ & $2(25)$ & $56(71)$ & $6(75)$ & $86(69)$ \\
\hline & 重れ飾り & 0 & 0 & 0 & 0 & 0 & $4(5)$ & 0 & $4(3)$ \\
\hline & 彩色 & 0 & 0 & 0 & T(5) & 0 & $3(4)$ & 0 & $4(3)$ \\
\hline & $\begin{array}{l}\text { アーチ } \\
\end{array}$ & 0 & 0 & 0 & $5(27)$ & 0 & $2(3)$ & 0 & $7(6)$ \\
\hline & 浮䧓 & 0 & 0 & 0 & $5(27)$ & 0 & $7(9)$ & 0 & $12(10)$ \\
\hline & その他 & 0 & 0 & $2(40)$ & 0 & $1(13)$ & $3(4)$ & 0 & $6(5)$ \\
\hline \multirow{4}{*}{$\begin{array}{c}\text { 上部前面の } \\
\text { 装飾要素 }\end{array}$} & $\begin{array}{l}\text { 帯状彫刻 } \\
\end{array}$ & 0 & $3(60)$ & 0 & $12(63)$ & $3(38)$ & $22(28)$ & $2(25)$ & $42(34)$ \\
\hline & フード & 0 & 0 & 0 & 0 & $8(100)$ & $22(28)$ & 0 & $30(24)$ \\
\hline & アーケード & 0 & 0 & 0 & 0 & 0 & $10(13)$ & 0 & $10(8)$ \\
\hline & その他 & 0 & 0 & 0 & $1(5)$ & 0 & 0 & 0 & 1(1) \\
\hline \multicolumn{2}{|c|}{ 該当ニッチ数 } & 38 & 9 & 14 & 26 & 8 & 91 & 8 & 194 \\
\hline
\end{tabular}

\section{$K$ : 下部に用いられる装飾要素}

\begin{tabular}{|c|c|c|c|c|c|c|c|c|c|}
\hline \multicolumn{2}{|c|}{ 下部装飾 } & 7th & 9th & 10th & 11th & 12th & 13th & 14th & 計 \\
\hline \multicolumn{2}{|c|}{ 装飾なし } & $16(42)$ & $9(100)$ & $9(56)$ & $18(69)$ & $8(100)$ & $72(81)$ & $6(75)$ & $138(71)$ \\
\hline \multicolumn{2}{|c|}{ 装飾あり } & $22(58)$ & 0 & $7(44)$ & $8(31)$ & 0 & 17(19) & 2(25) & $56(29)$ \\
\hline \multirow{6}{*}{$\begin{array}{c}\text { 下部の } \\
\text { 装飾要素 }\end{array}$} & 害 & $12(55)$ & 0 & 2(29) & 2(25) & 0 & $2(12)$ & 0 & $18(32)$ \\
\hline & 見切緑 & $8(36)$ & 0 & $4(57)$ & $4(50)$ & 0 & 0 & 0 & $16(29)$ \\
\hline & 付柱 & $10(46)$ & 0 & $1(14)$ & 0 & 0 & 0 & 0 & $11(20)$ \\
\hline & \begin{tabular}{|l|} 
アーケード \\
\end{tabular} & 0 & 0 & 0 & 0 & 0 & $11(65)$ & 0 & $11(20)$ \\
\hline & 連続半円紋様 & 0 & 0 & 0 & 0 & 0 & $2(12)$ & $2(100)$ & $4(7)$ \\
\hline & その他 & 0 & 0 & 0 & $2(25)$ & 0 & $2(12)$ & 0 & $4(7)$ \\
\hline \multicolumn{2}{|c|}{ 該当ニッチ数 } & 38 & 9 & 16 & 26 & 8 & 89 & 8 & 194 \\
\hline
\end{tabular}

\section{L：上部周囲に用いられる装飾要素}

\begin{tabular}{|c|c|c|c|c|c|c|c|c|c|}
\hline \multicolumn{2}{|c|}{ 上部周囲装飾 } & 7th & 9th & 10th & 11 th & 12th & 13th & 14th & 計 \\
\hline \multicolumn{2}{|c|}{ 装飾なし } & $29(83)$ & $4(44)$ & $2(13)$ & $9(35)$ & $6(100)$ & $48(54)$ & $8(100)$ & $106(56)$ \\
\hline \multicolumn{2}{|c|}{ 装飾あり } & $6(17)$ & $5(56)$ & $14(87)$ & 17(65) & 0 & $41(46)$ & 0 & $83(44)$ \\
\hline \multirow{3}{*}{$\begin{array}{l}\text { 上部周囲の } \\
\text { 装飾要素 }\end{array}$} & フード & $6(100)$ & $5(100)$ & 13(93) & $5(29)$ & 0 & $16(39)$ & 0 & $45(54)$ \\
\hline & アーケード & 0 & 0 & $1(7)$ & 12(71) & 0 & $27(66)$ & 0 & $40(48)$ \\
\hline & その他 & 0 & 0 & 0 & $1(6)$ & 0 & 2(5) & 0 & $3(3)$ \\
\hline \multicolumn{2}{|c|}{ 該当ニッチ数 } & 35 & 9 & 16 & 26 & 6 & 89 & 8 & 189 \\
\hline
\end{tabular}

\section{$M$ : 下部周囲に用いられる装飾要素}

\begin{tabular}{|c|c|c|c|c|c|c|c|c|c|}
\hline \multicolumn{2}{|c|}{ 下部周囲装飾 } & 7th & 9th & 10th & 11th & 12th & 13th & 14th & 計 \\
\hline \multicolumn{2}{|c|}{ 装飾なし } & $33(94)$ & $9(100)$ & $12(92)$ & $14(54)$ & $8(100)$ & $62(70)$ & $8(100)$ & $146(78)$ \\
\hline \multicolumn{2}{|c|}{ 装飾あり } & $2(6)$ & 0 & $1(8)$ & $12(46)$ & 0 & $27(30)$ & 0 & $42(22)$ \\
\hline \multirow{2}{*}{\begin{tabular}{|l} 
下部周囲の \\
装飾要素
\end{tabular}} & アーケード & 0 & 0 & $1(100)$ & $12(100)$ & 0 & $27(100)$ & 0 & $40(95)$ \\
\hline & 見切緑 & $2(100)$ & 0 & 0 & 0 & 0 & 0 & 0 & $2(5)$ \\
\hline \multicolumn{2}{|c|}{ 該当ニッチ数 } & 35 & 9 & 13 & 26 & 8 & 89 & 8 & 188 \\
\hline
\end{tabular}

上 $1,500 \mathrm{~mm}$ 未満、12 世紀以降では $500 \mathrm{~mm}$ 以上 $1,000 \mathrm{~mm}$ 未満の開 口幅をもつ外壁面ニッチがそれぞれ多くみられ、年代が下るにつれ て幅の狭いものが多くなる傾向が認められる。一方、奥行（表 $2 \mathrm{~F}$ ) については、全体的な傾向として、9世紀までは $500 \mathrm{~mm}$ 未満の外 壁面ニッチがないのに対し、特に 12 世紀以降においては $500 \mathrm{~mm}$ 未 満が多くみられる。各創建年代ごとにみると、7 世紀では $1,000 \mathrm{~mm}$ 
以上 $1,500 \mathrm{~mm}$ 未満、9〜11 世紀では $500 \mathrm{~mm}$ 以上 $1,000 \mathrm{~mm}$ 未満、12 世紀以降では $500 \mathrm{~mm}$ 未満の奥行の外壁面ニッチが多く、年代が下る につれて、奥行の浅いものが多くなる傾向にある。以上より、当初は 開口幅と奥行の点で、ある程度の大きさをもっていた外壁面ニッチか ら、年代が下るにつれて、幅が狭く、奥行の浅い、小さな外壁面ニッ チへと推移する変化を指摘できる。

壁面の厚さに対する外壁面ニッチの奥行の比 $\alpha$ （表 2G）について、 創建年代ごとにみると、7、9 世紀では $\alpha$ の值が 1 以上、つまり奥行 が壁厚よりも深いものが多くみられたのに対し、 $\alpha$ が 0.5 未満とな る、壁厚の半分以下の浅い外壁面ニッチは用いられていない。一方、 10、11 世紀になると、 $\alpha$ が 1 以上のものが依然多いものの、0.5 以 上 1 未満のものの占める割合も高くなっており、12 世紀では、 $\alpha$ が 0.5 以上 1 未満のものが、 13 世紀以降では 0.5 未満のものがそれぞ れ最も多くなっている。以上より、年代が下るにつれて、壁厚に対 して奥行の浅い外壁面ニッチが多く用いられる傾向がみてとれる。

c. 構法:外壁面ニッチ上部の構法 (表 $2 \mathrm{H}$ ) を分類ごとにみると、「単」 の構法は、9 世紀以前では用いられない一方、10 世紀から 14 世紀 創建までの遺構において合計 87 例(全体の $47 \%$ ) で確認されている。 各創建年代の外壁面ニッチ数に対する「単」の割合は、11 世紀か ら 12 世紀を境に高くなっている。一方、「複/単」の構法は、12 世 紀を除き、時代を通じて合計 63 例（全体の 33\%）で認められ、「単」 に次いで多い。創建年代ごとに「複/単」の使用割合をみると、9 世紀から 11 世紀において特に多い。「複」の構法は、7 世紀から 13 世紀創建までの遺構において合計 33 例で使用されるが、創建年代 ごとの使用割合をみると、7 世紀において最も多く用いられた反面、 その後年代が下るにつれて、少なくなる傾向にあるといえる。以上 より、11 世紀までは「複」、「複/単」等の複数の石材を組む構法が 多く用いられていたのに対し、12 世紀以降においては、9世紀まで にはみられなかった「単」の形式、すなわち単一の石材を据える構 法が多く用いられる傾向を指摘できる。

d. 装飾 : 外壁面ニッチに装飾が用いられるか否か（表 2I）につい てみると、7、9世紀では装飾のないものも比較的多く認められるが、 10 世紀以降、殆どの事例で、何らかの装飾が設けられている。

区分ごとにみていくと、外壁面ニッチ上部（表 2J）では、7 世紀 では装飾が全くみられないのに対し、9 世紀以降からは装飾が認め られるようになると、特に 11 世紀以降において装飾が施される割 合が多くなっている。外壁面ニッチ上部における、主として半円錐 面となる面（以下、上部内面と呼称する。図 2 参照）に設けられる 装飾要素としては、「放射状彫刻」が 9 世紀以降のニッチにおいて 多く認められる。その他、「垂れ飾り」「彩色」「アーチ」「浮彫」な どの使用がみられるが、全体として数は少ない。一方、外壁面ニッ チ上部に抢ける、教会堂の主要外壁面前面と面が一致する部分（上 部前面と呼称する。図 2 参照）においては、最も多く認められる、 植物文様等の装飾帯である「帯状彫刻」が、9 世紀以降比較的多く 用いられており、9 世紀及び 11 世紀では、装飾が設けられている ニッチの半数以上を占めている。次に多い「フード」は 11 世紀以 前にはみられない一方、12 世紀以降において認められる。また、「ア ーケード」は 13 世紀にのみ用いられている。

外壁面ニッチ下部（表 $2 \mathrm{~K}$ ）では、創建年代ごとにみると、7世 紀における半数以上の外壁面ニッチに装飾の使用が認められるが、
年代が下るにつれて無装飾のものが多くみられるようになり、特に 11 世紀以降では、無装飾の割合の方が高くなっている。装飾が多 く認められる 7 世紀において用いられる装飾要素としては、「空」、 「見切縁」、「付柱」が挙げられる。このうち、「空」は、7、10、11、 13 の各世紀に使用が認められ、装飾を有する外壁面ニッチの半数 以上を占めている。「見切縁」については、9世紀を除き、7〜 11 世紀までみられるが、12 世紀以降には認められない。一方、7、10 世紀でみられる「付柱」については、11 世紀以降では使用されて いない。「アーケード」は、12 世紀まで用いられることなく、13 世 紀にのみ使用が認められ、13 世紀における装飾を有する外壁面二 ッチの半数以上を占めている。「連続半円紋」は 13 世紀以降にのみ 見られ、14 世紀のニッチの全てにおいて施されている。

外壁面ニッチ上部周囲における装飾（表 2L）について、まず創建 年代ごとにみると、7 世紀には無装飾のものが比較的多い一方、9〜 11 世紀には装飾の使用が多くなり、その後再び無装飾のものが多く なっている。具体的な装飾要素としては、7 世紀から「フード」が 多用され、各創建年代の外壁面ニッチ総数に対する使用割合をみる と、無装飾である 12、14 世紀を除き、10 世紀まで、その使用割合は 高い。一方、「アーケード」は、9 世紀以前にはみられないが、10 世 紀以降より用いられ、11、13 世紀において使用割合が高くなっている。 外壁面ニッチ下部周囲における装飾（表 $2 \mathrm{M}$ ）では、7 世紀から 14 世紀に至るまで総じて無装飾のものが多いが、11 世紀及び 13 世 紀には装飾のある外壁面ニッチが比較的多く認められる。装飾要素 についてみると、比較的装飾の多い $11 、 13$ 世紀において、装飾を 有する外壁面ニッチの全てに「アーケード」の使用が認められる。

\section{4. 外壁面ニッチの特質}

この節では、前節で示した外壁面ニッチの形態的な傾向を総括し た上で (4.1)、この傾向と既往研究での議論を踏まえて、外壁面二 ッチの特質を検討する $(4.2)$ 。

\section{1 各分類項目からみた外壁面ニッチの形態的傾向}

位置に関する項目からは、外壁面ニッチが年代を通じて、教会堂 東面に多用されるという傾向をみてとれた。内部平面におけるアプ スとの対応関係では、7 世紀と 9 世紀において内部平面にアプスの ある面に外壁面ニッチが用いられる傾向が強いのに対し、10 世紀 以降、この対応関係が薄れている。7 世紀における該当事例が、い わゆるリプシメ型 ${ }^{19)}$ を中心としており、この平面形式が内部の東 西南北にそれぞれアプスを有するものであることから、特にアプス との対応関係が傾向として強く出たものと捉えられる。一方、9世 紀以降、時代が降るにつれ、いわゆるドーム・ホール型（表 1 中 $\mathrm{dh}$ 、図 2 参照）や修道院型（表 1 中 mo、図 2 参照）をはじめ、内 部平面におけるアプスの平面形状は、集中形式の遺構を除くと、一 般に教会堂東側にのみ用いられることが多く、東面以外における外 壁面ニッチの使用は、結果として内部アプス平面と対応しない用法 となったといえる。

形状に関する項目では、外壁面ニッチの開口幅及び奥行が、それ ぞれ時代を追うごとに小さくなる年代的推移が認められた。壁厚に 対する奥行の深さの比 $\alpha$ の検討からも、7 世紀当初、建築の全体的 な形状に関わるほど相対的に大きなものだった外壁面ニッチが、次 第に壁厚の半分に満たないものへと変化したことが窺え、建築全体 
の形状に大きく関係する部位から、外壁面上の部分的な䇠みへと、 外壁面ニッチの取扱いが変化しているとみなせる。また、当初は幾 つかの種類があった水平断面形状は、時代を追うに従い三角形断面 へと収斂する一方、上部形状も幾つかの種類が混在していたものか ら、半円錐形状が主流となる傾向が認められた。外壁面ニッチ上部 における架構が、外壁面ニッチの垂直壁面に直接載るものであるこ とを考慮すると、外壁面ニッチ上部に半円錐形状が多く用いられ る傾向は、三角形断面が多用される傾向に符合したものといえ、12 世紀以降、半円錐形状十三角形断面という組み合わせによる外壁面 ニッチが、ひとつの形式として定型化したものといえる。

構法については、外壁面ニッチ上部において、複数石材による構 法から、単一の石材による構法への年代的な変化がみてとれ、この 年代的推移は、外壁面ニッチ上部における構法の簡易化とも捉えら れる。ここで、外壁面ニッチの大きさと、その上部構法との関係 を、外壁面ニッチの横幅を大きさの基準にみてみると（表 3)、単 一の石材による構法である「単」が 1,000 mm 未満を中心に認めら れるのに対して、複数石材による構法である「複/単」や「複」が、 $1,000 \mathrm{~mm}$ 未満のものにも使用される他、1,000 mm を超えて $3,000 \mathrm{~mm}$ 以上の大きな外壁面ニッチにまで広く用いられている。すなわち、 上部構法と外壁面ニッチの大きさとの間には一定の相関が認めら れ、このことは、外壁面ニッチ上部における構法の簡易化の傾向が、 外壁面ニッチの小型化に伴い、上部構法が簡便なもので足りるよう になったことを示すもの、ないしは構法の簡易化が図られる中で、 外壁面ニッチが小型化した可能性を考え得る ${ }^{20)}$ 。

装飾のありかたをみると、7 世紀には、外壁面ニッチ下部を除く と、いずれの部位も無装飾が多くを占めており、用いられる装飾要 素も、フードや見切縁、空、付柱と様々で、一定の形式をもつに至 っていない。その後、9 世紀から 10 世紀を境に、基本的に装飾の なされる部位として、外壁面ニッチの取扱いが変化していることが 確認された。10 世紀より装飾が高い割合で設けられるようになる と、11 世紀には外壁面ニッチのいずれの部分においても装飾が認 められるに至る。11 世紀では、外壁面ニッチ上部には放射状彫刻 と帯状彫刻、下部には見切縁、上部周囲にはフードとアーケード、 下部周囲にはアーケードと、多用される装飾要素が部位ごとに定ま っており、外壁面ニッチに施す装飾に一定の規範が生じているもの ともいえる。12 世紀以降では、13 世紀に上部周囲及び下部周囲に も装飾が認められるものの、これまでの傾向から一転して、装飾さ れる部位が外壁面ニッチ上部に特化される傾向にあり、ここで用い られる装飾要素として、それまでにも多用されてきた放射状彫刻と 帯状彫刻に加えて、フードが挙げられる。フードは、11 世紀までには、 外壁面ニッチ上部周囲において多用されていた装飾要素であることか ら、同じ装飾要素が外壁面ニッチ上部周囲から外壁面ニッチ上部へと、 使用される位置が時代を経て推移したものともみなせる。アーケード についても、用いられ始めた時期がフードに比べて遅いことから、傾 向としては顕著ではないが、当初は外壁面ニッチ上部周囲及び下部周 囲にのみ認められたものが、13 世紀には外壁面ニッチ上部及び下部に もみられるように、使用される位置が推移したものとも捉えられる。

\section{2 形態的傾向にみる外壁面ニッチの特質}

これまでの研究では、アルメニア建築における外壁面ニッチの機 能や使用される意味として、特に 7 世紀の事例に関して、壁体の重
表 3 外壁面ニッチ上部の構法別にみた、外壁面ニッチの開口幅

\begin{tabular}{|c|c|c|c|c|c|c|c|c|}
\hline 単 & 7th & 9th & 10th & 11 th & 12th & 13th & 14th & 計 \\
\hline$w<500 \mathrm{~mm}$ & & & $1(100)$ & $3(43)$ & & $16(24)$ & & $20(23)$ \\
\hline $500 \mathrm{~mm} \leqq \mathrm{w}<1,000 \mathrm{~mm}$ & & & & $4(57)$ & $6(75)$ & $41(63)$ & $6(100)$ & $57(66)$ \\
\hline $1,000 \mathrm{~mm} \leqq \mathrm{w}<1,500 \mathrm{~mm}$ & & & & & $2(25)$ & $8(12)$ & & $10(12)$ \\
\hline \multicolumn{9}{|l|}{$1,500 \mathrm{~mm} \leqq \mathrm{w}<2,000 \mathrm{~mm}$} \\
\hline \multicolumn{9}{|l|}{$2,000 \mathrm{~mm} \leqq w<2,500 \mathrm{~mm}$} \\
\hline \multicolumn{9}{|l|}{$2,500 \mathrm{~mm} \leqq \mathrm{w}<3,000 \mathrm{~mm}$} \\
\hline $\mathrm{w} \leqq 3,000 \mathrm{~mm}$ & & & & & & & & \\
\hline 該当ニッチ数 & & & 1 & 7 & 8 & 65 & 6 & 87 \\
\hline
\end{tabular}

\begin{tabular}{|c|c|c|c|c|c|c|c|c|}
\hline 単/単 & 7th & 9th & 10th & 11 th & 12th & 13th & 14th & 計 \\
\hline $\mathrm{w}<500 \mathrm{~mm}$ & & & & & & & & \\
\hline $500 \mathrm{~mm} \leqq w<1,000 \mathrm{~mm}$ & & & & & & $3(100)$ & & $3(75)$ \\
\hline $1,000 \mathrm{~mm} \leqq \mathrm{w}<1,500 \mathrm{~mm}$ & & & & $1(100)$ & & & & $1(25)$ \\
\hline $1,500 \mathrm{~mm} \leqq \mathrm{w}<2,000 \mathrm{~mm}$ & & & & & & & & \\
\hline $2,000 \mathrm{~mm} \leqq \mathrm{w}<2,500 \mathrm{~mm}$ & & & & & & & & \\
\hline $\begin{array}{c}2,500 \mathrm{~mm} \leqq \mathrm{w}<3,000 \mathrm{~mm} \\
\mathrm{w} \leqq 3,000 \mathrm{~mm}\end{array}$ & & & & & & & & \\
\hline 該当ニッチ数 & & & & 1 & & 3 & & 4 \\
\hline
\end{tabular}

\begin{tabular}{|c|c|c|c|c|c|c|c|c|}
\hline 複/単 & 7th & 9th & 10th & 11 th & 12th & 13th & 14th & 計 \\
\hline \multicolumn{9}{|l|}{$w<500 \mathrm{~mm}$} \\
\hline $500 \mathrm{~mm} \leqq \mathrm{w}<1,000 \mathrm{~mm}$ & & & $4(36)$ & $1(7)$ & & $16(89)$ & $2(100)$ & $23(37)$ \\
\hline $1,000 \mathrm{~mm} \leqq \mathrm{w}<1,500 \mathrm{~mm}$ & & $2(29)$ & $5(46)$ & $6(40)$ & & & & $13(21)$ \\
\hline $1,500 \mathrm{~mm} \leqq \mathrm{w}<2,000 \mathrm{~mm}$ & $5(50)$ & $5(7)$ & $2(18)$ & $6(40)$ & & $1(6)$ & & 19(30) \\
\hline $2,000 \mathrm{~mm} \leqq \mathrm{w}<2,500 \mathrm{~mm}$ & $3(30)$ & & & $2(13)$ & & $1(6)$ & & $6(10)$ \\
\hline $2,500 \mathrm{~mm} \leqq \mathrm{w}<3,000 \mathrm{~mm}$ & $2(20)$ & & & & & & & $2(3)$ \\
\hline \multicolumn{9}{|l|}{$\mathrm{w} \leqq 3,000 \mathrm{~mm}$} \\
\hline 該当ニッチ数 & 10 & 7 & 11 & 15 & & 18 & 2 & 63 \\
\hline
\end{tabular}

\begin{tabular}{|c|c|c|c|c|c|c|c|c|}
\hline 複 & 7 th & 9th & 10th & 11 th & 12th & 13th & 14th & 計 \\
\hline \multicolumn{9}{|l|}{$w<500 \mathrm{~mm}$} \\
\hline $500 \mathrm{~mm} \leqq \mathrm{w}<1,000 \mathrm{~mm}$ & & & $1(50)$ & & & $2(100)$ & & $3(9)$ \\
\hline $1,000 \mathrm{~mm} \leqq \mathrm{w}<1,500 \mathrm{~mm}$ & $11(41)$ & $2(100)$ & & $2(100)$ & & & & $15(43)$ \\
\hline $1,500 \mathrm{~mm} \leqq \mathrm{w}<2,000 \mathrm{~mm}$ & $3(11)$ & & $7(50)$ & & & & & $4(11)$ \\
\hline $2,000 \mathrm{~mm} \leqq \mathrm{w}<2,500 \mathrm{~mm}$ & 9(33) & & & & & & & $9(26)$ \\
\hline $2,500 \mathrm{~mm} \leqq \mathrm{w}<3,000 \mathrm{~mm}$ & $2(7)$ & & & & & & & $2(6)$ \\
\hline$w \leqq 3,000 \mathrm{~mm}$ & $2(7)$ & & & & & & & $2(6)$ \\
\hline 該当ニッチ数 & 27 & 2 & 2 & 2 & & 2 & & 35 \\
\hline
\end{tabular}

表3注：凡例は表2に準ずる。

量を減らすためのもの ${ }^{21)}$ 、教会堂内陣の位置する東側を強調する

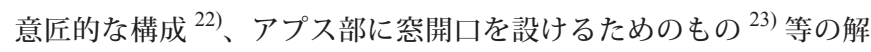
釈が与えられてきた ${ }^{24)}$

事実、前述のように、外壁面ニッチは時代を通じて東壁面に多用 される傾向にある。一般に、アルメニア建築における内部平面東側 は、内陣のある半円形平面（アプス）であり、外壁面ニッチはその 背面の両脇に対として配置される。壁体重量の軽減という見解は、 外壁面ニッチの多くが、内部アプスがなければ厚い壁体が生じる位 置に外壁面ニッチが設けられている点を根拠としている。また、本 稿で検討した、7 世紀の遺構における外壁面ニッチが、方角にかか わらず内部アプスの背後に位置することから、7 世紀当初は、東と いう方位よりは内部アプスとの関係は確かに強いものと考えられ る。ただ、実際に 7 世紀における外壁面ニッチ自体が大きいこと から、外壁面ニッチの設置により壁体重量の軽減を実現していると はいえるものの、これを外壁面ニッチを設ける一義的な理由をここ に求めるほど、十分な根拠が示されてはいない。特に、時代が下る につれて外壁面ニッチの大きさが全般的に小さくなっており、重量 軽減の機能もこれに合わせて低減している。

一方、外壁面ニッチと、その内部への空開口の設置との関係につ いてみると、ニッチ下部における空開口は、特に 7 世紀創建の遺構 に認められる。窓開口のあるいずれの例も、アプス部に3つの空を

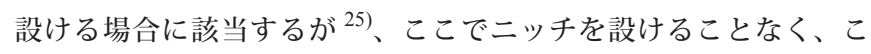
れらの空開口を設置すると仮定すると、空開口に対して壁厚が厚い ことから、3つの空のうち両脇の空の奥行は相当程度深くなり、採 光という空本来の機能を充分果たせない可能性が高い。すなわち、 


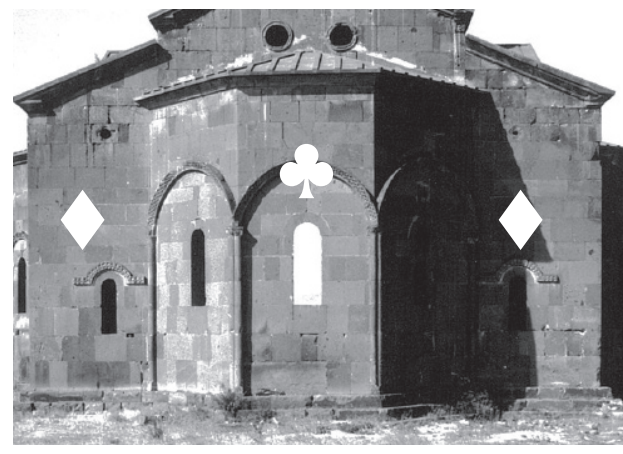

図 8 外部におけるアプス部の突出

(Talin/Kathoghike, 7th cen.)

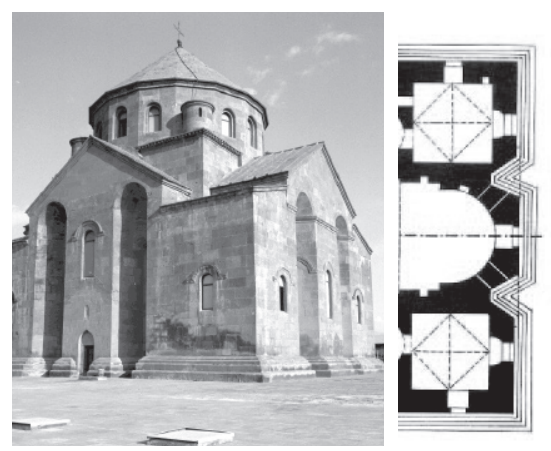

図 9 アルメニア建築における

建築外形と屋根架構

(Vagharsgapat/S. Hripsime, 7th cen.)

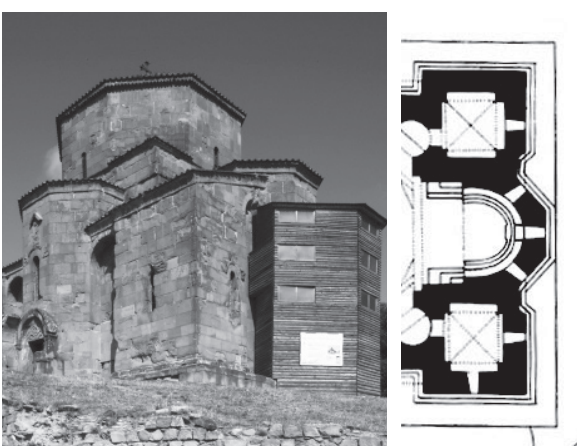

図 10 グルジア建築における建築外形と 屋根架構（Mtskheta/Dzvari, 6-7th cen.)
アプス形状に合わせて外壁面を多面体とすることは、空の採光機能 を確保する観点からすれば合理的といえる。実際、3つの空開口を アプス部に設ける際には、7 世紀創建の Talin/Katoghikeのように、 アプス部を外部に突出させることで外部形状を多面体に形成してい

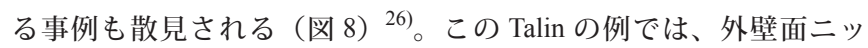
チは設けられないが、これはアプス部が側室部の壁面より外側へ突 出しているためと捉えられる。換言すれば、外壁面ニッチは、アプ ス部に対応する多面体の外壁面の中央面（図 8 中中部分）と、両側 室部の外壁面（図 8 中 部分）とが一つの面上に一致することで生 成されるものともいえる。このとき、外壁面ニッチ上端の収まりを みると、専ら半円錐形となるスキンチ状の石組が設けられることか ら、外壁面ニッチの設けられた壁面全体がひとつの面を構成し、結 果として切妻形状の屋根架構によるアプス部のヴォリュームの内接

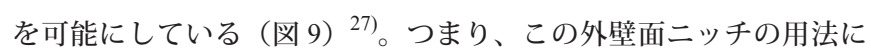
より、上述の Talin の遺構のような、複雑とも言える放射状の屋根 をアプス部上部に架構することが回避されているとみなせる。管見 の限りでは、アルメニア建築においては基本的に、建築外形に合わ せて外形が決定されており、矩形平面の上部には切妻ないし片流れ の屋根が、多角形平面の上部には放射状の屋根が架構されている。 実際、外形が矩形平面となる、検討対象としたアルメニア建築の全 てに扔いて、切妻屋根と片流れ屋根による比較的単純な形状の屋根 架構が架構されている。この際、内部平面の形状は様々であり、特 定の内部平面形式に偏在してはいない。

前述したように、アルメニア建築と同時期に発展した、周辺地域 の建築群であるグルジア正教の教会堂建築（以下、グルジア建築と 呼称する）にも、外壁面ニッチが使用されているが、今日残ってい る遺構に限れば、外壁面ニッチを有する 7 世紀の遺構は、Tsromi を 除くといずれもジュヴァリ型教会堂に該当している ${ }^{28)}$ 。のジュ ヴァリ型は、アルメニア建築におけるリプシメ型に準ずる平面形式 といえるが、同様の外壁面ニッチを用いながらも、リプシメ型にお ける外壁面ニッチに比してやや奥行が浅く、アプス部の壁面と側室 部の壁面が揃わずに、アプス部が突出している（図 10）。その結果 として、この部分に架かる屋根架構は、内部ヴォリュームの形状に対 応して分節された、放射状屋根を含む複雑な構成となっており、前述 図 9 の Vagharshapat/S. Hripsime における単純な切妻と片流れ屋根の組み合 わせとは異なっている。グルジア建築における外壁面ニッチの意味に ついては改めて考察する必要はあるが、外壁面ニッチの構成を使用す る点で類似しているとみなされてきた初期のアルメニア建築とグルジ

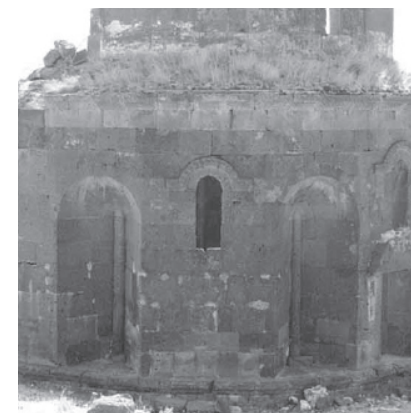

図 11 八葉形平面の教会堂 において屋根架構を簡易化する

(Yeghvard/Zoravar, 7th cen.)

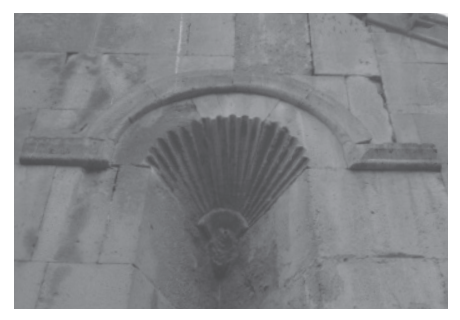

複数の石材からなるフード (Bjni/S. Astvatsatsin, 11th cen.) 外壁面ニッチ

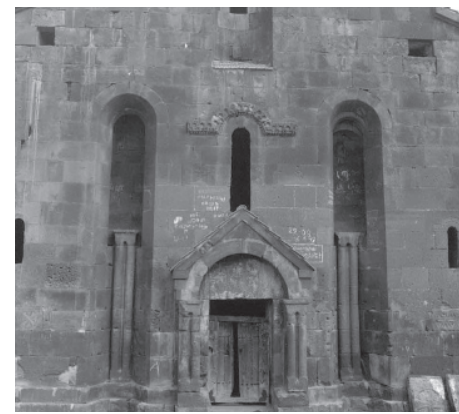

図 12 装飾的構成としての 外壁面ニッチ (Garnahovit/S. Gevorg, 7th cen.)

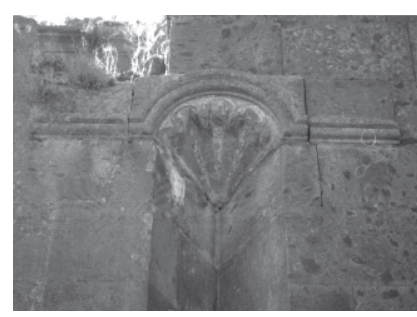

外壁面ニッチ上部構成材と一体的なフード (Astvatsenkal/S. Nshan, 13th cen.)
図 13 外壁面ニッチ上部及び上部周囲に設けられたフード状装飾

ア建築も、詳細にみるとその用法は一様でないことを指摘できる ${ }^{29)}$

こうした外壁面ニッチによる外部屋根架構の形状への配慮は、 アルメニアの多葉形平面の教会堂でも認められる。八葉形平面の Yeghvard/Zoravarでは、外壁面ニッチを設けることで、外壁面ニッ チを用いなければ八角形となる外部平面形状を 16 角形へと変換し、 外壁面ニッチ上部にスキンチ状の構成を据えることで、スキンチ状 の構成を用いずにそのまま内部形状を外形に反映させた場合に生じ る、凹凸を有する複雑な軒形状となる屋根架構を回避し、16 角錐 台形状に単純化している（図 11、図2 参照） ${ }^{30}$ 。 。一般に、集中形 式の建築物の屋根架構においては、より円形に近いほうが安定的で あることを考慮すれば、外壁面ニッチにより安定的な架構を実現し ているものとも捉えられ ${ }^{31)} 、 7$ 世紀のアルメニア建築における外壁 面ニッチのもつ大きさが、上述した建築外形や屋根の納まりに関係 する可能性をも示しているといえる。また、アルメニア建築を成立 させているラブル・コア工法は、建築形状に併せて、その表層石材 自体を整形する必要がある点で、建築形状を近似的に整形すること のできる煉瓦造等に比べると、施工上の精度と作業量が求められる 
と推察されるが、外壁面ニッチを用いることで凹凸のある複雑な形 状から単純な 16 角形平面の外形へと単純化され、複雑な形状の石 材の作成が回避されている点では、施工という側面からの合理性が あるものとも解釈できる ${ }^{32)}$ 。この点は、S. Hripsime とジュヴァリ型 教会堂との比較にみた架構の単純化に併せて生じる外壁面の平滑化 にも通じており、外壁面ニッチが納まりのための部位としての機能 を有していた蓋然性の高さを示していると捉えられる。

一方、同じ 7 世紀において、Garnahovit 西面の例のような、同 時代のものに比して、やや小さい外壁面ニッチも認められる（図 12)。外壁面ニッチの設置位置としては内部アプスに対応してはい るものの、壁体に対して奥行がやや浅い上、高さも低く、窻開口も ないことから、これまでに指摘した各機能を一義的に担うものと は考えにくい ${ }^{33)}$ 。外壁面ニッチに付与される装飾要素をみても、7 世紀では、一般に外壁面ニッチ下部を除くといずれの部位も装飾を もたない傾向にあり ${ }^{34)}$ 、装飾要素を付帯させることで建築外壁面 を飾るという外壁面ニッチの用法は、この時代において主流とはい えないが、Garnahovitのこの事例では、外壁面ニッチ内部に、特定 の機能をもたない装飾的な構成と捉えられる二重柱が内蔵されてお り、7 世紀の時点で、外壁面ニッチ自体が壁面に対する装飾的な構 成ないしはその一部としても取り扱われていたと考えられる ${ }^{35)}$ 。

その後、前述の通り、9 世紀以降、時代が降るに従い、小さく浅 いニッチが多くなる傾向にある。こうした外壁面ニッチは、その大 きさから、壁体を軽減する機能や屋根架構の簡易化の機能をもつには 効果が薄いと捉えられる点と、外壁面ニッチにおける装飾要素の使用 が 10 世紀から定着した傾向とを諶酌すれば、外壁面ニッチが小さく浅 くなるこの傾向は、この時期より、建築外壁面を装飾する構成として の外壁面ニッチの位置づけが強まっていったことを示すものといえる。 特に 10 世紀以降、内部平面のアプス形状とは関係なしに外壁面ニッチ が設けられるようになる傾向も、初期の段階で認められたアプスとの 対応に乘離が生じたものと解釈でき、空開口の設置や壁体の軽減の観 点からは、外壁面ニッチが使用されていないものといえる。

装飾要素として多用されるモチーフとしては、放射状彫刻、帯状 彫刻、フード、アーケードを指摘できたが、アーケードを除けば、 いずれも外壁面ニッチの上方を装飾するものとして共通している。 特にフードは、7世紀からみられる装飾要素でもあり、初期のうち から、外壁面ニッチに対する装飾の規範として外壁面ニッチの上 方へ装飾する志向があったものとみられる。これは、同じ外壁面上 に認められる空開口が、外壁面ニッチ同様にその上部を半円形とし ており、窓開口でも装飾として専らフードが用いられる志向と共通 し、その後も時代を通じて認められることから、上部が半円形のも のに対する装飾的な規範としてフードが存在したものといえる ${ }^{36)}$ 。 外壁面ニッチの上方への、これらの装飾要素の用法をみると、放射 状彫刻及び帯状彫刻では、外壁面ニッチ上部にその使用位置が固定 されている。その一方、フードについては、全般的な傾向として、 9〜11世紀頃には外壁面ニッチ上部周囲における専一的な使用がみ られるのに対して、12世紀以降、外壁面ニッチ上部にも多く設けら れるに至っている。この時期は、上部構法において、複数石材を組 んだ構法から、単一の石材を据える構法へと収斂した時期と合致 しており、それまで外壁面ニッチ上部より上方に位置する、外壁 面ニッチ上部周囲に設けられていたフード (図13左) が、楣状の単
一石材に内蔵される例が散見される（図13右）。こうした事例から は、外壁面ニッチの装飾化に際して、その上端を強調するという 装飾要素の使用形式が7世紀のうちから採用され、定着するととも に、外壁面ニッチの小型化と、それに伴う上部構法の簡易化に合わ せて、外壁面ニッチ上部の石材に装飾要素を内蔵させることで、外 壁面ニッチにおける装飾の設置を集約して、施工をより簡便なもの にしているものと捉えられる。一方、アーケードによる装飾的構成 は、10世紀より用いられるようになった後、11世紀に定着し、13世 紀にも引き続き用いられている。10世紀の例は1例のみだが、11世 紀には、専ら上部周囲と下部周囲に設けられており、その後13世紀 には上部や下部にも用いられる。この傾向も、フードの検討におい てみられたのと同様、装飾要素を外壁面ニッチの構成石材へと集約 する傾向として捉えることができる。

以上のように、外壁面ニッチの形態に関する検討からは、建築内 部平面におけるアプス形状と外壁面ニッチとの非対応化、外壁面二 ッチの定型化（三角形断面 / 半円錐形にみる形状の画一化、及び装 飾要素の画一化)、外壁面ニッチの小型化、外壁面ニッチを構成す る石材の構法の簡易化、装飾要素の表層石材への集約化と解釈でき る時代的な変化が、各分類項目において認められた。また、外壁面 ニッチが担った機能について、特に 7 世紀の事例における、内部平 面のアプスと外壁面ニッチの位置と空開口の存在、建築外形等を踏 まえて考察すると、外部屋根架構とその周辺の納まりを簡易化する 機能を新たに見出すことができた。定型化や小型化といった形態的 な扱いの時代的な変化と、今回指摘した外部屋根架構の納まりに対 する機能の他、これまで指摘されていた、壁体重量の軽減や空開口 のための壁面形状の操作といった機能の有効性の適否を総合して考 えれば、総じて、外壁面ニッチ自体が 7 世紀当初の段階でになって いたと捉え得る各機能は次第に失われ、建築壁面上の装飾的な構成 としての外壁面ニッチへと、その外壁面における建築部位としての 位置づけが収斂していったものと考えられる。

\section{5. 結論}

アルメニア建築における外壁面ニッチの構成について、位置、形 状、構法、装飾の 4 つの分類項目の設定に基づいて検討すると、い ずれの分類においても、時代とともに形態的な特質に変化が生じて いることが認められた。また、外壁面ニッチの存在意義についての 検討として、その機能について考察すると、これまで指摘されてき た壁体重量の軽減や空開口のための壁面形状の操作といった機能も 想定できる一方で、外部屋根架構と外壁面ニッチとの取り合いなど の検討から、外部屋根架構の納まりを形状として簡易化する機能 が、同じく 7 世紀における外壁面ニッチに見出されるに至った。新 たに見出された機能を含め、外壁面ニッチに想定される各機能と、 上述の形態的な特質の変化から導出される年代的な傾向、すなわち 外壁面ニッチと内部アプス形状との非対応化、定型化、小型化、構 法の簡易化、装飾要素の集約化といった形態の変化を鑑みるに、7 世紀当初において担われていた外壁面ニッチの諸機能は時代を追う ごとに失われ、およそ装飾的な構成としての機能に特化されていっ たものと捉えられる。ここに示した時代的な変化や機能は、これま でのアルメニア建築研究では指摘されてこなかったものであり、新 たな外壁面ニッチの特質の発見といえる。 
外壁面ニッチのもつ機能については、無論、今回指摘した外壁面 ニッチの機能を一義的なものとして限定されるものではなく、上述 のような既往研究における指摘にある機能をはじめ、教会堂の外観 を印象づける外壁面上の美的効果を狙った意匠的な要素等の機能を 有していた点を否定するものではない。しかし、4-2 で検討したよ うに、ラブル・コア工法という、表層石材の加工によって建築外形 が決定される建築工法に基いて建築物を建てる際に生じると予想さ れる、その構法的な論理から敷衍して考察する限り、これまでの研 究では検討されてこなかった、建築形状の納まりという新たな機能 が導出されるものであり、アルメニア建築の特質の一端を再解釈す ることができた点で、本稿はまた意義をもつものといえる。

外壁面ニッチに対する検討項目としては、今回の検討の他、フー ドなどの装飾帯や外壁面ニッチ上部を構成する石材自体に施されて いる彫刻におけるモチーフなどが考え得るが、こうしたモチーフ は、フードに限らず、軒等に使用される見切縁や、入口開口周囲の 枠等にも類似したものが涩められることから、これらの装飾的な構 成を横断した分析がむしろ妥当といえ、今後の課題としたい。また、 今回の検討で認められた、装飾要素の画一化や構法の簡易化といっ た変化は、外壁面ニッチに限らず、その他の装飾的な部位や壁面を 構成する石材の構法にも関係するものと考えられ、今後併せて検討 すべき課題と捉えられる。

注

1) 藤田康仁他、「ドーム架構形式からみたアルメニア共和国の初期教会堂 の系譜一アルメニア共和国におけるキリスト教建築の研究 $1 」$ 、日本建築 学会計画系論文集、第554号、日本建築学会、2002年

2) 岡本晋二郎他、「アルウチの教会堂に関する復元的考察」、アルメニア 共和国における中世の集中形式宗教建築の保存対策、科学研究費補助金平 成 10 年度国際学術研究、平成11 1 12 年度基盤研究A（2）研究成果報告書 （課題番号：100411138）、横浜、2001、pp177-197; 齋藤元嗣他、「初期ア ルメニア教会堂建築リュプシメ聖堂の調査報告 その 2 : アルメニア共和国 におけるキリスト教建築の研究 13」、日本建築学会関東支部第73回研究 報告会報告集 II、2004、pp.481-484; 篠野志郎他、「初期アルメニア教会堂 建築リュプシメ聖堂の調査報告 その 3 : アルメニア共和国におけるキリス 卜教 s 建築の研究 $14 」$ 、日本建築学会関東支部第73回研究報告会報告集 II、2004、pp.485-488

3) 藤田康仁他、「中世アルメニアキリスト教会堂建築の㲅意匠の特質一ア ルメニア共和国に打けるキリスト教建築の研究 $2 」$ 、日本建築学会関東支 部第70回研究報告会報告集、2000、pp.621-624; 藤田康仁他、「中世アルメ ニアキリスト教会堂建築の柱構成の特質一アルメニア共和国におけるキリ ス卜教建築の研究6」、日本建築学会関東支部第71回研究報告会報告集、 2001、pp.621-624; 藤田康仁他、「初期アルメニアキリスト教会堂建築の彫 刻装飾の特質一アルメニア共和国におけるキリスト教建築の研究 $9 」$ 、日本 建築学会関東支部第71回研究報告会報告集、2002、pp.473-476

4) Cuneoのカタログに所収されている研究対象年代（4世紀から14世紀）の教 会堂 457 棟のうち、129棟に外壁面ニッチの使用が認められている。総数 457棟には、小さな礼帱堂も含んで扔り、外壁面ニッチを有する一定程度 の規模の遺構に母数を限った際の、外壁面ニッチの使用割合はもう少し高 いといえる。Cf. Cuneo, P., Architettura Armena, Roma, 1988

5) Alpago-Novello, A., The Armenians, Milano, 1986

6) アルメニア建築に扔ける外壁面ニッチについて、その概要や機能等に ついて考察した研究として、以下のものが認められる。Khachatrian, A., A Propos Des Niches Exterieures dans L'Architecture Armenienne, Synthoronon, pp.69-73; Eremian, A., Sur Certaines Modifications Subies Par Les Monuments Armeniens Au VIIe Siecle, Revue des Etudes Armeniennes, 1971, pp.251-266 Khatchatrianによる論考では、初期におけるアルメニア建築に認められる外 壁面ニッチを取り上げて考察を行っている。ここでは、アルメニア建築の 比較対象としてローマ建築におけるマウソレウムを引用し、これら放射状 の平面をもつ建築物の外部に認められる壁龖が、アルメニア建築における
外壁面ニッチへと変化したものと主張している。この分析では、基本的に 平面形態にのみ注目した分析がなされており、図形的な類似性から、アル メニア建築とローマ建築を結びつけている点で短絡的ともいえ、また、外 壁面ニッチの機能や立体的な形状については看過されている。さらに、取 り扱うアルメニア建築の事例や比較対象となる事例も限定的であり、十分 な検討がなされているとはいえない。 Eremianによる論考では、本論考の 主題である、教会堂東側に設けられるアプス部における3つの空開口の意 味に関する考察に関連して、東面に扔ける外壁面ニッチが、空開口を設け るための部位であることが指摘されている。しかし、外壁面ニッチが本論 考の主題ではないため、空開口との関連性に触れるに留まっており、外壁 面ニッチについて考察を深めるには至っていないといえる。また、注3に 示した藤田他の論考では、東京工業大学篠野研究室による一連の研究で は、彫刻装飾に関する論考において外壁面ニッチを取り扱っているが、外 壁面ニッチの形態的な特徵については限定的であり、外壁面ニッチを構成 する諸要素について詳しく分析するには至っていない。

7)これまでに現地調査に及んだ現存するアルメニア建築のうち、外壁面 ニッチを有する教会堂の総数は72棟であるが、その全てについて創建年 代が明らかになっていない。本稿では、外壁面ニッチの年代的な傾向を 正確に把握するため、碑文や文献などに基いて、創建年ないし創建年代 が比較的明確に分かっている教会堂のみを対象とし、結果として45棟が 分析対象として抽出されるに至っている。本稿で明らかになった年代的 傾向から編年指標を抽出することで、創建年代の不明確な遺構に対して 創建年代の推定を行うことが可能であるが、紙幅の関係上、本稿では検 討していない。別稿として、将来的には改めて検討したい。なお、この 地域以外にもアゼルヴァイジャン共和国やイラン・イスラーム共和国に もアルメニア建築は広く分布しているが、比較的年代の新しいものが多 く、対象年代に創建された遺構の分布地域としては、ほぼ遺漏のない地 域設定といえる。また、10世紀から11世紀にかけて創建されたMarmashen のKatoghikeについては、本稿では便宜的に11世紀に創建されたものとし て取り扱っている。Cf. Cuneo, P., op. cit.; Hasratian,M., Essai sur l'architecture Armenienne, Moscow, 1985; Hakhpat: Document of Armenian Architecture , vol.1, Milano, 1968; Ani: Document of Armenian Architecture vol.12, Milano, 1984; Ketcharis: Document of Armenian Architecture vol.11, Venezia, 1982; Cuneo, P., Le Couvent de Marmashen et l'Ecole Architectuale d'Ani, 1992; Haghartzin: Document of Armenian Architecture vol.13 , Milano, 1984; Gandzasar: Document of Armenian Architecture vol.17, Venezia, 1987; T.A.Sinclair, Eastern Turkey: an Architectual and Archaeological Survey Vol.1, London, 1987

8) 本研究に関連する科学研究費補助金は以下の通りである。「キリスト 教・イスラーム文化混淆地域の歴史的遺構にみる建築技術の展開と交 流」、研究課題番号 : 21254004、基盤研究(A) ・ 海外学術調查、研究代 表者：篠野志郎、2009-; 「中世アルメニア正教教会堂建築における壁面 装飾意匠に関する研究」、研究課題番号：21760500、若手研究(B)、研 究代表者：藤田康仁。2009-2011; 「東部アナトリア地域の歴史的建築遺 構における建築技術の交流と特質に関する調查・研究」、研究課題番 号：18404017、基盤研究(B) ・ 海外学術調査、研究代表者：篠野志郎、 2006-2008; 「アルメニア共和国における中期キリスト教遺構の調査・研 究-アルメニア共和国のキリスト教遺構の保存対策-」、研究課題番号 : 14404011、基盤研究(B) - 海外学術調查、研究代表者：篠野志郎、20022004; 「アルメニア共和国における中世の集中形式宗教建築の保存対 策」、研究課題番号：10041138、基盤研究(A) ・ 海外学術調査、研究代表 者：篠野志郎、1998-2000

9) 写真資料については、各遺構での調查において、遺構の内外表面に認め られる建築部位や分節を網羅的に撮影していることから、外壁面ニッチに ついても詳細な検討が可能である。なお、教会堂建築における外壁面ニッ チ固有の特質を明らかにするため、本稿では、修道院に扔ける教会堂の付 属施設であるガヴィットや鐘楼等を始めとする周辺施設に認められる外壁 面ニッチや、ドームを有する教会堂におけるドラム部に設けられていた外 壁面ニッチは、数量的な分析の対象から除外している。

10) Cuneo, P., op. cit. 平面図のデータについては、著者らによって独自に採取 された平面図との比較から判断して、Cuneoの著作所収の図面が一定程度 の正確さを有するものと考えられる。

11) 前述したように、Eremianでは、アプス部及びアプスに打りる空開口と外 壁面ニッチの関係が指摘されている。Cf. Eremian, A., op. cit.

12) 分析対象中、外壁面ニッチが対で用いられていない例は、集中形式を除 けば、Hovhannavankの一例のみであり、一般的にも稀といえる。

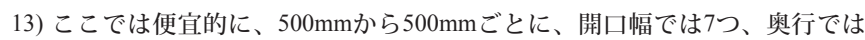


5つの度数区分を設定している。

14）ここでは便宜的に、aの值から壁厚の $1 / 2$ を基準に、3つの度数区分を設定 している。

15) 構法の分析については、この他外壁面ニッチ下部における構法として、 目地の連続性に関する検討を、また最下部にみられる基壇状石積につい て、外壁面ニッチ内部への石積の迴り达みに着目して検討を行ったが、詳 細な記載は紙幅の関係から本稿では割愛する。大まかな傾向を記しておく と、年代が下るにつれて、垂直壁面の右側及び左側の水平方向の切石目地 が連続なものが多くなる傾向を指摘できるが、基本的には切石目地は連続 するものと捉えられる。また、基壇状石積については、7世紀においては 基壇状石積が外壁面ニッチ内部に迴り込む形式が比較的多く用いられてい たが、9世紀以降においては、基壇状石積が外壁面ニッチ内部に組み込ま れないものが多く用いられる傾向にあったと指摘できる。

16) 外壁面ニッチにまつわる付加的な要素には、空開口のように、外壁面 ニッチ構成そのものを装飾するものではない要素も含まれるが、装飾的な 要素がほとんどであるため、この检討では、こうした直接的な装飾でない ものも、便宜的に装飾として取り扱うものとする。

17) 表2中で用いられているパーセンテージは、各創建年代の合計棟数に対 する各項目の棟数の割合を表しており、複数該当があるため、創建年代ご との合計は $100 \%$ を超える。また、ここでは、割合の多寊をみるため、便 宜的に $25 \%$ ごとに色分けをしている。なお、この色分けについては、他の 分類項目の表中に㧧いても使用している。

18) ここでは、外壁面ニッチが全壊していたとしても、平面図から断面形状 を確認できるものについては分析対象に含んでいる。

19) 該当するのは、Vagharshapat/S. Hripsime, Garnahovit/S. Gevorg, Sisavan/S. Hovhannesの3棟である。Cf. 篠野志郎他、初期アルメニア建築における リュプシメ形式教会の架構形式の系譜、日本建築学会計画系論文集、 vol.590、2005、pp.173-179

20）基壇状石積における、ニッチ内部への迴り込みが減少する傾向について も、それまで比較的大きな外壁面ニッチが設けられることで、ニッチの内 部も建築の外形と認識され、外壁下部全体を巡る基壇状石積が回りこんで いたものが、外壁面ニッチの小型化により、建築の外形とは認識されなく なったことによるものとも見なせる。

21) Khatchatrian, A., op. cit.

22) Ibid.

23) Eremian, A. B., op. cit.

24）また、ローマ建築におけるマウソレウムの外壁面ニッチに由来するとの 捉え方もなされている。Cf. Khatchatrian, A., op. cit.

25) 具体例として、Vagharshapat/S. HripsimeやSisavan/S. Hovhannesなどが挙げ られる。な打、3つの空については、単性説に近い教義を採るアルメニア 正教にもかかわらず、ギリシャ正教などからの影響とする三位一体の教義 との関連性が指摘されている。Cf. Eremian, A. B., op. cit.

26) 同様の空開口を有する突出したアプスの事例に、Mrenの教会堂やArtik, S. Sarkis（いずれも7世紀創建とされる。検討対象外）などが挙げられる。

27) スキンチ状に石材を組むことは、ドームを架構する際に、内部ドラム下 端にスキンチを用いる事例が6世紀より認められており、7世紀当時におい て十分知悉されていたものといえる。

28) Alpago-Novello, A., et.al., Art and Architecture in Medieval Georgia, Louvain la Neuve, 1980

29) この相違の意味については、グルジア建築における外壁面ニッチの検討 が必要であり、将来的な研究の進渉が望まれる。

30)なお、この遺構における外壁面ニッチには空開口が設けられていない。

31) 今回はドラム部外壁面に設けられたニッチを取り报っていないが、 Zoravarの例の他、Garnahovit/S. Gevorgや、検討対象ではないが、Irindや Mastara/S. Hovhannesなどの遺構（いずれも7世紀創建）において、ドラム 部においてもニッチの使用が確認されている。これらの例では、ドラム上 端において、ドラム外形の底面は八角形から16角形へと辺の数を増やして おり、その上部に架構される鍾状の屋根も、その底辺の数が増えることで、 形状的に安定した円錐により近い、多角錐形状の屋根を実現している。

32) 建築形状とラブル・コア工法との関係については、拙稿における考察を 参照されたい。Cf. 藤田康仁、「初期アルメニア正教教会堂建築の教会堂 主要部構成内部における上部架構の構築方法一アルメニア共和国における キリスト教建築の研究3-」、日本建築学会計画系論文集、vol.678、2012、 pp. 2201-2209

33) 架構にまつわる機能を担うには、一定程度の大きさを要すると考えられる。

34)下部に用いられる装飾的要素に葖や付柱があるが、これらが装飾的要素
であるとはいえ、ニッチそのものを強調するものではないことを考える と、7世紀には基本的に外壁面ニッチは装飾されていないとも見なせる。

35) Talin/Katoghikeにも、同様の柱構成の使用された外壁面ニッチが残されて いる。

36) 藤田康仁、篠野志郎、高橋宏樹、勝木祐仁、「中世アルメニア・キリス 卜教会堂建築の空意匠の特質ーアルメニア共和国におけるキリスト教建築 の研究2-」、日本建築学会関東支部 1999年度研究報告集、Vol. 70、2000、 pp.621-624 